\title{
ПРОФЕССОР Ф.Н. МИЛЬКОВ. МОСКВА. ДВИЖЕНИЕ В НАПРАВЛЕНИИ ИНТЕЛЛЕКТУАЛЬНОЙ ЭЛИТЫ
}

\author{
В. И. Федотов, С. В. Федотов \\ Воронежский государственный университет, Россия \\ Поступила в редакиию 10 августа 2019 г.
}

\begin{abstract}
Аннотация: В библиографической статье авторы рассматривают важнейший период жизни будущего профессора Ф.Н. Милькова. Московский период - это учеба в пединституте, аспирантские годы. В Москве произошло знакомство со знаковыми персонами в географической среде - Н. Н. Баранским, Г. Д. Рихтером, И. С. Щукиным, А. И. Соловьевым и другими.
\end{abstract}

Ключевые слова: студент, аспирант, университет, экспедиция, диссертация.

\section{Professor F. N. Mil'kov. Moscow. The movement towards the intellectual elite}

\section{I. Fedotov, S. V. Fedotov}

\begin{abstract}
In the bibliographic article the authors consider the most important period of the life of the future Professor F. N. Mil'kov. The Moscow period is a study at the pedagogical Institute, postgraduate years. In Moscow there was an acquaintance with the iconic persons in the geographical environment N. N. Baranskiy, G. D. Richter, I. S. Shchukin, A. I. Solovyov and others.
\end{abstract}

Key words: student, postgraduate student, university, expedition, dissertation.

В 1932 году сын потомственных крестьян Федор Мильков достигает Москвы - объявлен набор в школу фабрично-заводского обучения (ФЗО) треста Мособлполиграф по специальности печатник. В сентябре 1966 года в беседе с корреспондентом газеты «Воронежский университет» С. Фроловой он с гордостью замечает: «Я и Ваше газетное знаю. После ФЗУ работал печатником, имею пятый разряд».

Два года трудился Федор Мильков типографским рабочим. А в 1934 году после скоротечных подготовительных курсов в вуз поступает на географический факультет Московского областного педагогического института (МОПИ).

При выборе вузовской специальности пришлось решать, что же выбрать? Географию или литературу. «Друзья, - вспоминал Федор Николаевич, - советовали идти на литературный. И книги ты все-все перечитал. И стихи хорошие пишешь». Но любовь к географии оказалась сильнее.

В те годы на географическом факультете МОПИ работали известные впоследствии ученые-

() Федотов В.И., Федотов С.В., 2019

Материал статьи доступен по лицензии

Creative Commons "Attribution" 4.0 педагоги: Г. Д. Рихтер, В.С. Говорухин, Г. В. Горбацкий, И. М. Иванов. Учеба в вузе проходила со значительным увлечением научной работой. Студент Федор Мильков в течение всех лет обучения в МОПИ был председателем научного студенческого кружка (НСК) кафедры физической географии. Как вспоминала профессор Воронежского педагогического института М.П. Забродская, подруга и однокурсница жены Федора Николаевича, заседания НСК проходили при большом участии молодежи. Особенно много студентов собиралось на тех заседаниях, когда были объявления о выступлении с научным докладом председателя НСК.

Студента Федора Милькова привлекала большое внимание работа с научной литературой. В студенческие годы он начал создавать свою профессиональную библиотеку, где главное место занимала классическая литература по физической географии и естественно-научным направлениям - лесоведению, фитоценологии, биогеографии, учению о рельефе. Студент Мильков завсегдатай Московских книжных магазинов и их букинистических отделов. На полках книжного шкафа собрана была самая важная литература классиков естествознания - В. В. Докучаева, Г. И. Танфильева, 
И. К. Пачосского, В. Н. Сукачева, Г. Ф. Морозова и многих других.

Много позже в ноябре 1947 года, работая в Чкаловском (Оренбургском) педагогическом институте, Федор Николаевич признавался читателям «Чкаловской коммуны: «Учился с упоением. Я бы хотел узнать весь мир, сокровищницы высоких гор, моря, океаны, беспредельные русские равнины и леса». «Приехав в Москву из далекой Северо-Двинской губернии, - вспоминал Федор Мильков, - я не мог себе представить, что есть на свете такие города. Долгое время, обучаясь в Москве в фабрично-заводском училище печатников, я, словно очарованный, бродил у кремлевских башен. Всю сладость и величие русской культуры я познал в Москве».

После известного майского 1934 года Постановления Правительства СССР и ЦКВКП(б) «О преподавании географии в средней школе» в педагогических институтах и классических университетах стали создаваться географические факультеты. Московский областной педагогический институт не стал исключением. Уже в самом начале работы геофаков страны в их учебные планы была заложена идея практико-ориентированного обучения. Студенты географы МОПИ проходили учебную практику на только что организованной в 1935 году Мячковской географической станции в Раменском районе Московской области. И хотя педагогические институты не готовили своих выпускников специально для научно-исследовательской работы, но профессорско-преподавательский коллектив факультета прилагал значительные усилия к тому, чтобы привить студентам любовь к научным исследованиям. Собранный на станции полевой материал стал впоследствии основой для первых научных публикаций.

С первых курсов студенты-географы привлекались к участию в экспедициях и обработке собранных материалов. Студент Федор Мильков привлекается к работе в комплексной Калининской экспедиции Московского университета в качестве младшего геоботаника. Консультантом Федора Милькова был В. С. Говорухин. В Великолукском отряде Калининской экспедиции им был собран обширный материал по флористическому составу древесной растительности и взаимоотношениях еловых, сосновых и дубовых насаждений.

На последнем, выпускном, курсе обучения в МОПИ со студентом Федором Мильковым произойдет судьбоносный случай. Дело было так. «Физическую географию СССР» на геофаке ин- ститута читал профессор Иван Михайлович Иванов. Профессор И. М. Иванов имел договор с географическим факультетом Белорусского университета прочитать несколько лекций по «Физической географии Советского Союза». Однако, когда подошел срок выполнять договорные обязательства болезнь приковала профессора к постели. И тогда И. М. Иванов попросил студента-отличника Федора Милькова его выручить - съездить в Минск и прочитать несколько запланированных им лекций. Студент Федор Мильков соглашается. Этот уникальный эпизод студенческой поры Федор Николаевич вспоминал не без юмора много раз. «Поезд Москва-Минск, - рассказывал он, - с московским профессором собралась встречать представительная делегация - руководство факультета, преподавательский состав, студенческий актив, не было только духового оркестра. Когда на перрон вокзала вместо авторитетного профессора вышел студент-старшекурсник, встречающие были разочарованы. Но все прошло как нельзя нормально». Федор Николаевич Мильков, спустя не так много времени, будет десятки лет читать курс «Физическая география СССР» в Чкаловском пединституте и Воронежском государственном университете. Более того он станет автором популярного учебника «Физическая география СССР» для географических факультетов вузов России и союзных республик.

В 1938 году Ф. Мильков заканчивает географический факультет МОПИ с дипломом первой степени (диплом с отличием) и рекомендуется в аспирантуру Научно-исследовательского института географии (НИИГ) при Московском государственном университете (МГУ) имени М. В. Ломоносова. Прием в аспирантуру тех лет проходил не в форме традиционных экзаменов как теперь, а в виде собеседования. Председателем экзаменационной комиссии и собеседником у Федора Милькова был легендарный географ Николай Николаевич Баранский. Впервые увиденный им «живой» Баранский «требовал одинакового знания физической и экономической географии» [1].

Показательна в этом смысле беседа Н.Н. Баранского с претендентом на аспирантское место в НИИГе Федором Мильковым. Федор Николаевич вспоминал: «...узнав, что абитуриент из сельской местности быв. Северо-Двинской губернии, он тут же попросил рассказать о подсечно-огневой системе земледелия. В самом конце - вопрос: как приехать из г. Ош в г. Фрунзе» [1]. 
Руководителями аспирантов в НИИГе были авторитетные ученые - И. П. Герасимов, К. К. Марков, А. И. Соловьев, И. С. Щукин, А. И. Спиридонов, А. А. Борзов, Б. Ф. Добрынин, Н. Н. Баранский и другие.

Руководство НИИГа требовало от своих аспирантов педагогической работы по совместительству и участию в экспедициях. Аспирант Федор Мильков принимал участие в двух экспедициях трехнедельная экспедиция ИГ АН СССР по снеготаянию на Мячковской географической станции под руководством Г. Д. Рихтера весной 1939 года и комплексной Рязанской экспедиции 1939-1940 годов. Вторая, Рязанская, экспедиция ставила своей целью общее географическое описание только что организованной Рязанской области. Милькову было доверено руководить небольшим Паро-Пронским отрядом экспедиции. Материалы, собранные в бассейне реки Пары и на Паро-Пронском междуречье, вошли в диссертационную работу «Опыт характеристики ландшафтных районов северной лесостепи». По результатам Рязанской экспедиции Ф.Н. Мильковым были проведены оригинальные геоморфологические и ботанико-географические наблюдения. Так, он установил полигенетический генезис степных западин. По представлениям Федора Милькова западины - разнородные по происхождению первичные неровности равнинных поверхностей, в оформлении которых существенную роль сыграли суффозионные процессы [2].

Педагогическая работа привлекала многих аспирантов НИИГа. Федор Мильков пробовал свой педагогический опыт в двух образовательных учреждениях - 88-ая средняя школа Краснопресненского района города Москвы (учитель географии с сентября 1937 года по октябрь 1938) и в вузах столицы. На протяжении 3-х аспирантских лет Федор Мильков вел полевую практику студентов-географов МОПИ, а с марта 1941 года был зачислен на полставки ассистента в штат кафедры физической географии СССР МГУ.

НИИГ при МГУ на протяжении 20-х-50-х годов XX столетия стал подлинным центром подготовки кадров географов высшей квалификации для вузов большой страны. Ф.Н. Мильков по этому поводу пишет: «Наследие НИИГа МГУ - не одни географы Московского университета, вместе с ними - коллективы кафедр географии многих вузов страны, новые научные направления и школы, возглавляемые его учениками в первом и втором поколениях» [1]. Будет уместным здесь напомнить наиболее известных выпускников НИИГа -
Ю. Г. Саушкина, А. И. Спиридонова, Т. В. Звонкову, Н. А. Солнцева, М.В. Карандееву, Н. А. Гвоздецкого, Н. И. Михайлова, Г.К. Тушинского, А.А. Макунину, Т.В. Власову, Н.П. Неклюкову, Г. Т. Гришина и многих других.

Московский период жизни Федора Николаевича стал временем приобретения знакомых и друзей, входящих в состав географической элиты страны - Г. Д. Рихтера, В. С. Говорухина, А. А. Борзова, К. К. Маркова, Б. Ф. Добрынина, И. С. Щукина, А. И. Спиридонова, Д. Л. Арманда.

Финальным аккордом 9-летнего пребывания в Москве стала защита кандидатской диссертации в Ученом совете Московского университета. Она состоялась 13 июня 1941 года за 9 дней до начала Великой Отечественной войны. Первым оппонентом выступал сотрудник ИГАН СССР профессор И. П. Герасимов, вторым - кандидат географических наук Н. А. Солнцев. «В минуты большой радости, - писал Ф.Н. Мильков в газете «Чкаловская коммуна» 1 июня 1947 года, - пока меня поздравляли мои учителя, маститые профессора страны, я вспоминал горькую судьбу своего отца, весь век свой проработавшего на помещика. Ему бы стать тогда со мной рядом у кафедры и глядеть, как мужицкий сын завоевывает право стать ученым».

После девятилетнего пребывания молодого человека Федора Милькова в Москве им были достигнуты, прямо скажем, выдающиеся результаты. Во-первых, он в 20 лет получил высшее образование. Во-вторых, в 23 года защитил кандидатскую диссертацию. В-третьих, приобрел опыт педагогической работы в средней и высшей школе. В-четвертых, им были установлены рабочие и дружественные связи с научной элитой в области естествознания и географии - Г.Д. Рихтером, В. С. Говорухиным, И. П. Герасимовым, Н. Н. Баранским, И. С. Щукиным.

После защиты диссертации Ф.Н. Мильков получил бронь от призыва в Красную армию и был распределен на работу в Чкаловский (Оренбургский) педагогический институт.

\section{СПИСОК ЛИТЕРАТУРЫ}

1. Мильков Ф. Н. Похвальное слово о Научно-исследовательском институте географии МГУ: (к 75-летию со дня учреждения) / Ф. Н. Мильков // Вестник Московского университета. Сер. 5, География. - 1997. - № 3. - C. 3-8.

2. Михно В. Б. День памяти 4. Выдающийся географ-ландшафтовед (к 100-летия Федора Николаевича Милькова) / В. Б. Михно // Вестник Воронежского го- 
сударственного университета. Сер. География. Геоэкология. - 2018. - № 1. - С. 112-127.

\section{REFERENCES}

1. Mil'kov F. N. Pokhval'noe slovo o Nauchnoissledovatel'skom institute geografii MGU: (k 75-letiyu so dnya uchrezhdeniya) [A laudable word about the Research Institute of Geography of Moscow State University: (on

Федотов Владимир Иванович

доктор географических наук, профессор кафедры рекреационной географии, страноведения и туризма факультета географии, геоэкологии и туризма Воронежского государственного университета, г. Воронеж, т. (473) 266-56-54, E-mail: deanery@ geogr.vsu.ru

Федотов Сергей Владимирович

кандидат географических наук, доцент, заведующий кафедрой рекреационной географии, страноведения и туризма факультета географии, геоэкологии и туризма Воронежского государственного университета, г. Воронеж, т. (473) 266-56-54, E-mail: deanery@ geogr.vsu.ru the 75th anniversary of the founding)]. Vestnik Moskovskogo universiteta. Ser. 5, Geografiya, 1997, No. 3, pp. 3-8.

2. Mikhno V. B. Den' pamyati 4. Vydayushchiysya geograf-landshaftoved (k 100-letiya Fedora Nikolaevicha Mil'kova) [Memorial Day 4. An outstanding geographylandscape specialist (on the 100th anniversary of Fedor Nikolaevich Milkov)]. Vestnik Voronezhskogo gosudarstvennogo universiteta. Ser. Geografiya. Geoekologiya, 2018, No. 1, pp. 112-127.

Fedotov Vladimir Ivanovitch

Doctor of Geographical Sciences, Professor of the Department of Recreational Geography, Country Studies and Tourism, Faculty of Geography, Geoecology and Tourism, Voronezh State University, Voronezh, t. (473) 266-56-54, E-mail: deanery@geogr.vsu.ru

Fedotov Sergey Vladimirovitch

Candidate of Geographical Sciences, Associate Professor, Head of the Department of Recreational Geography, Country Studies and Tourism, Faculty of Geography, Geoecology and Tourism, Voronezh State University, Voronezh, t. (473) 266-56-54, E-mail: deanery@geogr.vsu.ru 